\title{
Are Rising Athletics Allocations Associated with Student Costs: Evidence from Public NCAA Division I Universities
}

\author{
Willis A. Jones \\ University of South Florida \\ Mike Rudolph \\ University of Kentucky
}

\begin{abstract}
Many in the higher education community criticize the millions of dollars in financial allocations given to intercollegiate athletics departments by universities on the premise that when universities have to provide more allocation money to athletics, student costs increase. Evidence supporting this argument, however, is largely anecdotal. This study used fixed effects regression analyses to explore whether year to year changes in university funds allocated to athletics lead to higher student costs. Our findings call into question the argument that rising athletics allocations are a significant direct driver of student costs.
\end{abstract}

Keywords: Intercollegiate Athletics, College Costs

In 2016-2017, colleges and universities spent $\$ 584$ billion on a broad array of expenses, including instruction, student support, and scholarships (U.S. Department of Education, 2019). As spending at postsecondary institutions has increased, constituents have raised concerns about how this spending impacts student access, affordability, and debt. As a result, postsecondary spending has been under heavy scrutiny in recent years, and many have called for higher education to look for ways to reduce expenditures (Balzer, 2020; Hoxby \& Strange, 2019).

One area of university spending in particular that has received scrutiny is athletics. Despite calls from many within the higher education community to curtail spending on intercollegiate athletics (Lederman, 2012), data indicate that college and 
university athletics costs continue to increase rapidly. Median expenditures on intercollegiate athletics among National Collegiate Athletic Association (NCAA) Division I universities increased 124\% between 2004 and 2016 (Fulks, 2017). Among athletics programs in the Big Ten, Big 12, Pacific-12, Southeastern Conference, and Atlantic Coast Conference, total spending on intercollegiate athletics increased from \$2.6 billion to \$4.4 billion between 2004 and 2014 (Hobson \& Rich, 2015a). According to the Delta Cost Project, athletics spending per student-athlete increased 51\% among Football Bowl Subdivision (FBS) universities, 61\% among Football Championship Subdivision (FCS) universities, and 39\% among NCAA Division I universities with no football program (Desrochers, 2013) ${ }^{1}$.

While expenditures on college athletics have increased rapidly, athletics revenues at many universities have increased at a much slower rate (Burnsed, 2014). As a result, very few athletics departments self-generate sufficient revenue to cover their expenses (Knight Commission on Intercollegiate Athletics, 2010). To cover budget shortfalls, many athletics departments receive financial allocations (also call subsidies) from the university ${ }^{2}$ (Denhart \& Ridpath, 2011). According to USA Today, allocations account for $\$ 1$ of every $\$ 3$ spent on athletics by public NCAA Division I universities (Fear, 2016). These allocations generally derive from two sources. Student athletics fees are mandatory fees assessed primarily (but not exclusively) to full-time undergraduate students that universities use to support intercollegiate athletics. Direct and indirect university funds (henceforth called university funds) are state support, direct support from the university's general fund, and indirect facilities or administrative support provided to intercollegiate athletics programs (USA Today Sports, 2017). In 2015, 130 NCAA Division I athletics departments relied on allocations for over half their total athletics department revenue (Wolverton et al., 2015).

Many commentators have suggested that athletics allocations are at least partially responsible for the escalating costs of higher education. Miller (2003) noted that while not solely responsible for the increasing costs of higher education, "to say that athletics are completely free from any blame would also be a great error" (p. 40). In his study of selective private colleges and universities, Ehrenberg (2000) noted that conscious decisions by institutions of higher education to add sports programs and build new athletics facilities contribute to the rising costs of a college education. The Center for College Affordability and Productivity (CCAP) in September 2010 released a report listing 25 ways to make higher education more affordable for students. Number eight in the report was to end what they called the "Athletics Arms Race" currently taking place among colleges and universities, especially among NCAA Division I schools (Center for College Affordability and Productivity, 2010, p. 66). At the heart of these arguments is the belief that when universities are forced to dedicate more financial resources to athletics programs, universities will look to recapture this money by increasing student costs (Berkowitz \& Upton, 2011; Knight Commission on Intercollegiate Athletics, 2010; Miller, 2003; Suggs, 2009).

While several studies have examined the role of athletics in general on college costs (Alexander \& Kern, 2009; Kelchen, 2016; Pope \& Pope, 2009), little empirical research has explored whether a direct statistical relationship exists between athletics department allocations (in particular university funds provided to athletics) and 


\section{Higher Education Politics \& Economics}

student costs. The purpose of this study was to begin addressing this knowledge gap. Specifically, we examined the following research question:

- Do yearly changes in university funds allocations to intercollegiate athletics programs correlated with three measures of student costs at public NCAA Division I universities?

\section{LITERATURE REVIEW}

Research on financial allocations to intercollegiate athletics has explored issues such as the role of athletics allocations within university budgeting (Phillips \& Olson, 2015; Rudolph, 2017), the driving forces behind increasing athletics allocations (Bass et al., 2015; Cheslock \& Knight, 2015; Kearney, 2014), and student knowledge of athletics allocations (Denhart \& Ridpath, 2011; Ridpath et al., 2015). Research on the relationship between athletics allocations and student costs, however, is scarce. While we found no empirical studies specifically testing whether rising athletics allocations correlate with student costs, we did find studies exploring the general role of athletics in student costs. One line of scholarship in this area explores the role of athletics success in student costs. Alexander and Kern (2009) used data from 19872007 to examine the impact of athletics success, as measured by win-loss records in football and men's basketball, on two measures of student costs; in-state and out-ofstate tuition rates. They collected data from 181 NCAA Division I and Division II public colleges and universities for the study. Their estimation models included controls for institutional type, conference affiliation, state per capita income, and institutional location. While the estimation findings differed slightly based on the type of regression model used, Alexander and Kern (2009) concluded that team success appeared to positively correlate with a university's published tuition and fee charges. In one estimation, the authors found that each additional football win correlated with a $\$ 28$ per student increase in in-state tuition and a $\$ 54$ per student increase in out-of-state tuition and fees. Basketball wins correlated with a $\$ 7$ per student increase in in-state tuition and fees and a $\$ 16$ per student increase in out-ofstate tuition and fees. Based on these findings, Alexander and Kern (2009) state "we can conclude that athletic success, at least on the gridiron, has some impact on tuition rates for both in-state and out-of-state students" (p. 250).

Pope and Pope (2009), in their study of the relationship between college sports success and student applications, also sought to determine whether sports success correlated with student costs. Student costs in this study were defined as the natural logarithm of real tuition at a school (no other conceptualization or operationalization of the variable was provided in the paper). Pope and Pope (2009) used a fixed-effects regression model with controls for professor salary, total cost of attendance, high school diplomas in a state, and per capita income. Using data from 332 NCAA Division I colleges and universities between 1983 to 2002, the authors found that private institutions increase tuition around $6 \%$ the year after their men's basketball program participated in the NCAA Men's Final Four. Football success, however, was not found to have a statistically significant correlation with private school tuition. 
Pope and Pope (2009) found no consistent evidence of a relationship between football or basketball success and student charges at public institutions.

Smith (2012) examined the relationship between athletics success and student costs using what he called a more inclusive definition of student costs and more robust estimation models than in other studies. Smith (2012) examined data from up to 348 NCAA Division I colleges and universities over a 16-year period (the author does not specify what 16 years were covered). Smith (2012) defined the dependent variable as published tuition, fees, and room/board charges for an institution. Smith included a number of state and institution covariates in his estimation model including undergraduate enrollment, average faculty salary, Carnegie classification, conference affiliation, portion of the state population between 18 and 24 years of age, and state per-capita income. Smith (2012) found that the relationship between various forms of football success and increases to tuition, room, board, and fees (considered together) was significant and institutions raised student costs substantially following a successful season. However, few significant relationships were observed between basketball success and student charges. Importantly, the relationship between football success and increases in tuition only was not significant. Only after tuition, fees, and room/board charges were considered together did significant relationships emerge.

Another line of research on the relationship between athletics and student costs has explored how athletics expenditures correlate with student fees. Kelchen (2016) used panel data from 2001-2012 to explore how changes in published student fees are affected by the magnitude of the athletics program. Spending on athletics was operationalized as the per-student institutional expenditures on intercollegiate athletics. Kelchen (2016) found that expenditures on intercollegiate athletics had "weak or nonexistent relationships with student fee levels" (p. 216).

While these previous studies on the role of intercollegiate athletics in student costs are valuable, what has been missing is an analysis of student costs relative to athletics allocations. This is especially important given that much of the commentary related to athletics allocations is focused only on student fees. Anecdotal stories about athletics programs being fueled by student fees are rampant throughout the popular media. For example, Minium (2015) noted that in Virginia several public institutions charge students over $\$ 1,000$ per year in student athletics fees. The Washington Post (Hobson \& Rich, 2015a, 2015b), The Huffington Post (Wolverton et al., 2015), and The Washington Times (Sherfinski, 2013) have also run stories noting the growth of student athletics fees and the potential impact of these fees on student costs. As noted earlier, however, athletics allocations come from two sources; student fees and university funds. There has very little empirical scholarship or popular press about university funds as a driver of student costs.

\section{Conceptual Framework}

In choosing a conceptual framework to ground this study, we looked for theories that could help us better understand two issues:

1)Why would a university continue to financially support the increasing costs associated with intercollegiate athletics? 


\section{Higher Education Politics \& Economics}

2) Why would universities, when forced to provide university funds to athletics, look to increase revenue via student tuition and fees rather than from other sources?

Bowen's (1980) revenue theory of costs is a framework that can help answer the first question. Revenue theory argues that as non-profit enterprises, costs containment is not a central driver of college and university decision making. Colleges and universities are instead driven by a nearly insatiable desire to maximize prestige and excellence. Bowen's (1980) theory is articulated in his five laws of higher education costs:

1. The dominant goals of institutions of higher education are educational excellence, prestige, and influence.

2. In quest of excellence, prestige, and influence, there is virtually no limit to the amount of money an institution could spend for seemingly fruitful educational ends.

3. Each institution raises all the money it can.

4. Each institution spends all it raises.

5. The cumulative effect of the preceding four laws is towards ever-increasing expenditures. (pp. 19-20)

Taken together, these laws argue that colleges and universities focus less on minimizing costs and instead focus on maximizing prestige. For many universities, athletics is part of this prestige maximization effort. Many administrators in postsecondary education see intercollegiate athletics as an important vehicle for increasing the prestige and legitimacy of a college or university (Fuller et al., 2017; Toma, 2010). A survey of presidents from NCAA Division I FBS universities found that most presidents believe athletics success helps a university gain national publicity, raises the profile of a university among elected officials, and improves the overall reputation of a university (Art \& Science Group, 2011). This belief about athletics, especially among trustees and administrators at NCAA Division I universities, helps explain why schools would continue to support athletics programs that fail to generate enough money on their own to cover their expenses. McEvoy et al. (2013) also use Bowen's theory to ground their work on the financial behavior of intercollegiate athletics programs.

As Bowen's (1980) revenue theory notes, in their pursuit of prestige and excellence, universities will raise all the money they can. Therefore, as expenditures for athletics allocations rise, universities will likely seek to increase revenues. While there are several revenues sources universities could pursue (such as endowment growth, philanthropy, etc.), we argue that increasing student tuition and fees is a more likely revenue generating strategy. We make this argument because student tuition is one of the few largely unrestricted revenue sources available to universities (American Academy of Arts and Sciences, 2016) and because tuition and fees have a relatively low demand elasticity (Ahmed \& Ghosh, 2012; Sherlock, 2011).

To summarize, we argue that institutions of higher education are motivated to provide university funds in part because of the desire to obtain greater levels of prestige and notoriety. When forced to increase expenditures on athletics, a likely source of additional revenue for a university is student tuition and fees. Therefore, it is reasonable to assume a statistical relationship might exist between the amount of 
university funds allocated to athletics and student tuition and fees. Based on this framework, evidence from studies on the relationship between athletics success and student costs, and statements from Miller (2003), Ehrenberg (2000), and the Center for College Affordability and Productivity (2010), it was hypothesized that a positive, statistically significant correlation exists between changes in university funds allocated to athletics and student costs the following year.

\section{DATA AND EMPIRICAL METHODOLOGY}

We obtained data for this study primarily from two sources. University funds were obtained from the College Athletics Financial Information Database housed by the Knight Commission on Intercollegiate Athletics (College Athletics Financial Information Database, 2020). Knight Commission data rely on information from the NCAA Membership Financial Reporting System (MFRS). Each year, NCAA member institutions are required to submit financial data detailing operating revenues and expenses related to its intercollegiate athletics program. For Division I institutions, the financial data are subject to agreed-upon procedures and verified by an independent accountant annually. These annual financial reports are unfortunately not made publicly available by the NCAA. Through public record requests to statesupported institutions of higher education competing at the NCAA Division I level, however, the Knight Commission is able to obtain some MFRS reports. These reports are aggregated and made publicly available at http:/cafidatabase.knightcommission.org/. Private institutions are not subject to public records requests, so the Knight Commission dataset consists of only public NCAA Division I college and universities ${ }^{3}$. Also, while institutional MFRS reports contain just over 40 individual revenue and expenditure categories, the Knight Commission database reports only a fraction of these data categories. The Knight Commission variable labeled 'institutional/government support to college athletics' was used as our measure of university fund allocations to athletics. At the time of this study, the Knight Commission databased contained data from 2004-2005 through 2016-2017 on 231 pubic NCAA Division I universities.

Other university-level data in this study were obtained from the Integrated Postsecondary Data System (IPEDS) administered by the U.S. Department of Education. IPEDS is a system of surveys conducted annually by the National Center for Education Statistics to obtain data from every postsecondary institution that participates in federal student financial aid programs. These data include university enrollments, program completions, graduation rates, student financial aid, and university prices. Appendix I list the variables used in this study and their sources.

The base empirical model strategy in this study was a fixed effects regression model of the following form:

Student Costsit $=\beta_{0}+\beta_{1}$ University funds $_{\mathrm{it}-1}+\sum \beta_{\mathrm{j}} \mathrm{X}_{\mathrm{jit}-1}+\gamma \mathrm{i}+\eta \mathrm{t}+\varepsilon_{\mathrm{it}}$ where subscript $i$ represents universities and subscript $t$ represents time.

Three measures of student costs (Student Costsit) were used as outcome variables in this study. The first outcome measure was published in-state student costs. In-state student costs was operationalized as published tuition and required fees for full-time, first-time undergraduate students meeting the university's 


\section{Higher Education Politics \& Economics}

residency requirements for in-state status. The second outcome variable was the published tuition and required fees for full-time, first-time undergraduate out-of-state students (students who do not meet the university or state residency requirements for in-state status). The final measure of student costs used was net student costs. Net student costs is the average net price for full-time, first-time degree/certificateseeking undergraduates paying the in-state rate who received grant or scholarship aid from federal, state/local governments, or the university.

The primary independent variable of interest in equation 1 was university funds (university fundsit-1). As noted earlier, university funds are revenue allocated to intercollegiate athletics that fall into one of four categories:

- State, municipal, or federal government support-government funding specifically earmarked for the athletics department by government agencies for which the institution of higher education cannot reallocate.

- Direct institutional support- funds provided by the institution to athletics for the operations of intercollegiate athletics.

- Indirect institutional support- the value of costs covered and services provided by the institution to athletics but not charged to athletics.

- Indirect institutional support for athletics facilities debt service, lease, and rental fees- Debt service payments, leases and rental fees for athletics facilities provided by the institution to athletics but not charged to athletics.

Equation 1 specifies a one-year lag between university funds and published student costs. To illustrate the logic behind this decision, we use an example from student tuition setting for a single year, 2012-13. We assume that most public universities set tuition for the 2012-13 during spring 2012. Tuition for 2012-13 was likely finalized for most public universities by July 2012. Universities were making these tuition decisions with knowledge of the amount of university fund money given to athletics in the 2011-12 academic year. Drawing from Bowen's (1980) framework, we argue that during tuition setting procedures for the 2012-13 academic year, universities could look to increase revenue from tuition and fees to cover what was spent on athletics in the 2011-2012 year. Therefore, the independent variable of interest in model estimations was lagged by one year. This lag strategy is common among researchers looking to model student college costs (Alexander \& Kern, 2010; Pope \& Pope, 2009; Smith, 2012).

Control variables $\left(\sum \beta_{\mathrm{j}} \mathrm{X}_{\mathrm{jit}-1}\right)$ were included in Equation 1 to reduce omitted variable bias and increase the precision of the $\beta_{1}$ estimate. We specifically focused on observable, time-varying covariates that plausibly affect student costs and correlate with the amount of university funds given to intercollegiate athletics. After conducting a literature review on the determinants of in-state and out-of-state tuition levels among public colleges and universities (Burgess, 2011; Delaney \& Kearney, 2014; Doyle, 2012; Ehrenberg, 2000; Koshal \& Koshal, 2000; Rizzo \& Ehrenberg, 2004), it was decided that three covariates lagged by one year would be included in model estimations.

University revenue is a commonly discussed predictor of student costs. It is also reasonable to assume that the amount of revenue obtained by a university correlates with the amount of money available for allocation to athletics. To control for this, our estimation models included a measure of core revenue received by a 
university in year $t$-1. IPEDS (2020) defines core revenue as total revenues received from tuition and fees, government appropriations, government grants and contracts, private gifts, grants, and contracts, investment income and other operating and nonoperating sources of financial support. Core revenue excludes revenues from auxiliary enterprises, hospitals, and independent operations. It is important to note that while tuition and fee revenue is measured within this core revenue covariate, core revenue is lagged by one year in our estimation models (i.e., core revenue from 20112012 is used to predict student costs for 2012-2013). This eliminates potential endogeneity concerns from student tuition and fees being captured in both the dependent variable and independent variable. Post-hoc estimation of models using core revenue minus tuition and fees revenue as a covariate produced similar findings to those reported here.

Another commonly discussed determinate of student tuition and fees is university expenditures. As a university uses more of its operating budget on educational and general expenditures, it may seek more tuition from students to cover costs. Changes in university expenditures, however, might also correlate with the amount of money available for allocation to athletics. To address this concern, our estimation models included a measure of university expenditures per full-time equivalent (FTE) student in the areas of instruction, research, and public service. Instructional expenditures were all operating expenses associated with the colleges, schools, departments, and other instructional divisions of the university. Research expenditures were all operating expenses associated with activities specifically organized to produce research outcomes at a university. Public service expenditures were all operating expenses associated with activities established primarily to provide non-instructional services beneficial to individuals and groups external to the university.

While there are many other non-athletics related university expenditures, we limited our measure of expenditures to research, instruction, and services in part because we wanted to ensure that the expenditure control variable did not capture our independent variable of interest. Given the definitions of the various expenditure categories in IPEDS, we believe university expenditures on athletics allocations are likely captured within IPEDS reported academic support expenditures, student services expenditures, student success expenditures, university support expenditures, and/or scholarship/fellowship expenditures. Therefore, including any of these in our expenditure measure might create multicollinearity concerns. Our assumption is that expenditures on athletics allocations are not contained within IPEDS reported instructional, research, or public service expenditures for a university.

The final control variable used in the model was undergraduate enrollment. Basic economic principles of supply and demand suggest that increased demand can create upward pressure on tuition levels (Rizzo \& Ehrenberg, 2004). One could also reasonably assume that increased enrollment at a university (a common measure of university demand) would lead to a greater number of students participating in intercollegiate athletics or athletics-related activities (such as cheerleading), which could result in higher athletics costs and therefore increased need for university funds. To address this, model estimations included undergraduate FTE enrollment for a university in year $t-1$. 


\section{Higher Education Politics \& Economics}

The remaining variables in Equation 1 represented a university $(\gamma \mathrm{i})$ and a time fixed-effect $(\eta t)$. University specific fixed-effects controlled for time-invariant or very slowly changing university characteristics that could correlate with student costs and athletics allocations such as university location, "flagship" designation, or academic reputation. The time fixed-effect captured any systematic changes to higher education (such as national economic conditions or federal aid policy) that could impact student costs and university funds in a given year. Given the panel nature of our data, the fixed-effects strategy helps minimize omitted variable bias by allowing us to control for unobserved heterogeneity due to stable unmeasured variables that differ across universities (Allison, 2009; Rabe-Hesketh \& Skrondal, 2008).

In addition to our base regression model, we estimated models that included interaction terms to explore whether the relationship between athletics allocations and student costs was moderated by a third variable. The first variable we explored was university tuition setting authority. We hypothesized that universities located in states where tuition setting authority is at the university board level might be more responsive to changes in university funds relative to universities where tuition setting authority is more centralized at the state board or state legislature level. Using information from the Education Commission of the States (Zinth \& Smith, 2012), we grouped universities into three categories; schools located in states where tuition was set at the campus board level, schools located in states were tuition was set at the state board of education/higher education level, and schools located in states were tuition was set at legislature level.

We also used university type as a moderating variable. Different university types often have different budgeting and accounting structures as it relates to determining student costs. Therefore, it is possible that athletics expenditures at different types of universities relate to student costs differently. To test this, we divided our sample into two groups using data from the 2015 Carnegie Classification; research universities (very high research activity research, high research activity, or doctoral/research universities) and non-research universities (master's colleges/universities and baccalaureate colleges).

The final moderating variable used was university funds as a percentage of total university expenditures. If university funds to athletics are only a small portion of a university's overall budget, a university might not respond to changes in athletics allocations by immediately increasing student costs the next year. To explore this hypothesis, we divided university funds to athletics by a university's total operating and non-operating expenditures. This quotient was interacted with our independent variable of interest in model estimations.

All financial data in this study were inflation adjusted to 2017 values using the Consumer Price Index (CPI) published by the U.S. Bureau of Labor Statistics. Natural logs were used for all dollar values and enrollment measures to address skewness in the distribution of our variables and ease the interpretation of the relationships in our models.

Some important limitations of the methodology and data used in this study should be considered. Some have argued that data from sources like the College Athletics Financial Information Database can be misleading (Dosh, 2013; Wunderlich, 2013). Every university does its accounting somewhat differently. When it comes to 
athletics revenues and expenditures, what is and is not 'put on the books' may lack consistency across universities. Therefore, the definition of university funds can vary from university to university. Because the parameters estimated in this study focus on within-university changes over time, however, cross university variations in the operationalization of university funds to athletics would be captured by the university fixed-effect and should not greatly impact our findings. We do note, however, that not every college/university in our dataset likely had the same definition of university funds. It is also possible that an individual university's method of accounting or reporting athletics financial data could vary because of personnel or policy changes from year to year. These year to year changes are not captured in our estimation models.

Our empirical model assumes that, after controlling for covariates, there is no correlation between the independent variable of interest and the error term. This exogeneity assumption, however, is violated if an unmeasured (or unmeasurable) university characteristics captured in the error term correlates with the amount of university funds allocated to athletics. For example, an unmeasurable 'prestige push' initiated by a new university president or board chair could lead a university to simultaneously invest more in its athletics program and raise student tuition and fees. Other difficult-to-measure variables that might create omitted variable bias include institutional decisions to build or upgrade stadiums/arenas or the on-field success of an institution's athletics program. We were unable to capture these in our models. So while we include time-varying controls and fixed effects in our estimation model in an effort to obtain an unbiased estimation of the university funds-student costs relationship, we acknowledge that unmeasurable variables could lead to a violation of our exogeneity assumption.

We also acknowledge that there are multiple moderating variables which could be used to further explore the relationships in this study such as conference affiliation, NCAA Division I subdivision affiliation, whether an institution is a member of the 'Power 5', etc. Given the space limitations of the journal, however, we limited the number of models reported in this paper. While we chose to focus on three moderating variables, there is certainly room for future research in this area which focuses on other structural distinctions between colleges and universities.

\section{RESULTS}

Of the 231 universities in the College Athletics Financial Information Database, five were excluded from our final analyses. Two universities (Pennsylvania State University and University of Delaware) were dropped because the schools failed to report revenue and expenditure data to IPEDS. The United States Military Academy and United States Air Force Academy were dropped because student costs are covered upon admission at military academies (meaning these universities do not report student costs). Finally, Kennesaw State University was dropped because the school had several years of missing data across many variables used in this study.

The remaining 226 universities served as the analytic sample for this study. Figures 1 and 2 graph per year median values for the three dependent variables and one independent variable of interest in this study. As expected, that data showed an 


\section{Higher Education Politics \& Economics}

upward trend for university funds and student costs. University funds allocated to athletics increased 69\% from 2005-2017. Student costs showed a slightly less steep slope, with net price increasing $16 \%$, in-state tuition and fees increasing $44.1 \%$, and out-of-state tuition and fees increasing $31.1 \%$.

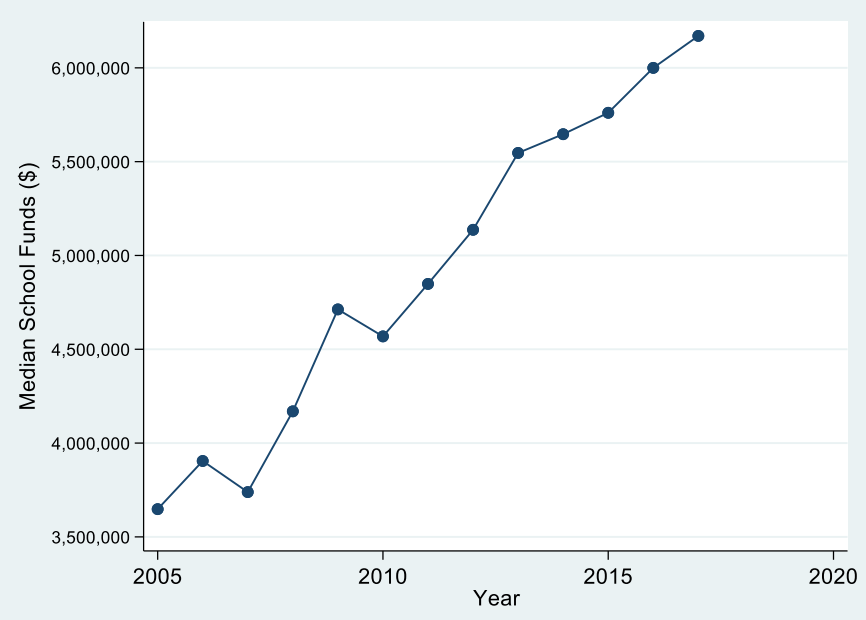

Figure 1. Per year median school funds allocated to athletics among public NCAA Division I colleges and universities from 2005-2017.

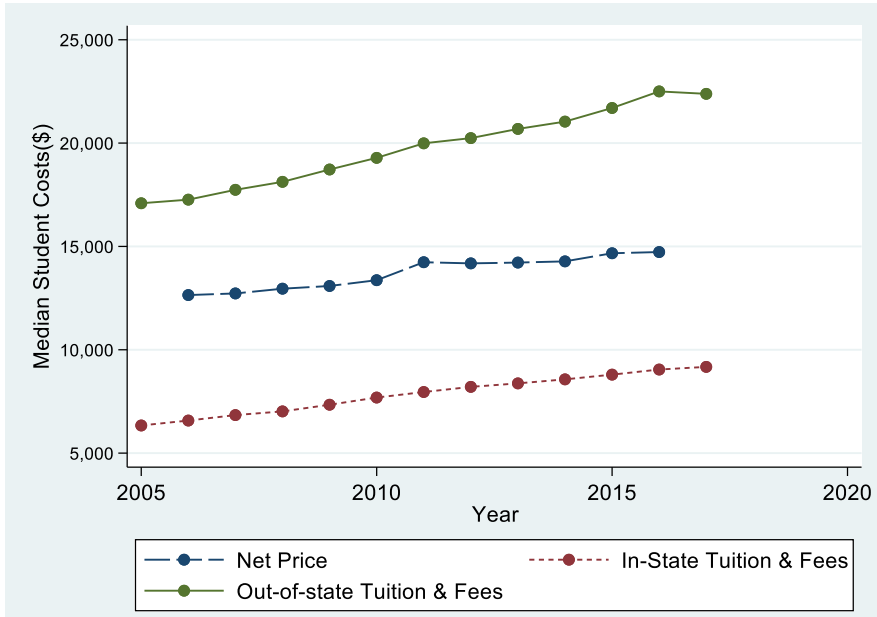

Figure 2. Per year median student costs among public NCAA Division I colleges and universities from 2005-2017.

Table 1 provides descriptive statistics on the primary variables used in this study. Given the longitudinal nature of the data, Table 1 presents the overall mean in addition to between and within-group variation in the variables. Several pieces of important information should be noted from this table. The number of observations 
on net price is lower than with other variables. This is because net price data were only available in IPEDS from 2005-2006 through 2015-2016. University funds has a T-bar value of 12.58. This tells us that there were some university-year observations missing for the university funds variable. The missing data appear to have two sources. First, several universities simple failed to provide financial information to the College Athletics Financial Information Database in some years. For example, Chicago State University failed to provide university funds data from 2005-2009 and again failed to provide data in 2014. Other universities in the dataset were members of NCAA Division II for several years between 2005 and 2017. In the years in which a university was a member of Division II, the College Athletics Financial Information Database did not provide athletics financial data. For example, Northern Kentucky University was a member of Division II from 2005-2012 before moving to Division I. During the years in which the university was in Division II, university funds data were not reported. University-year observations with missing values for university funds were dropped from analyses.

\section{Table 1}

\section{Descriptive Statistics for Variables Used in the Study}

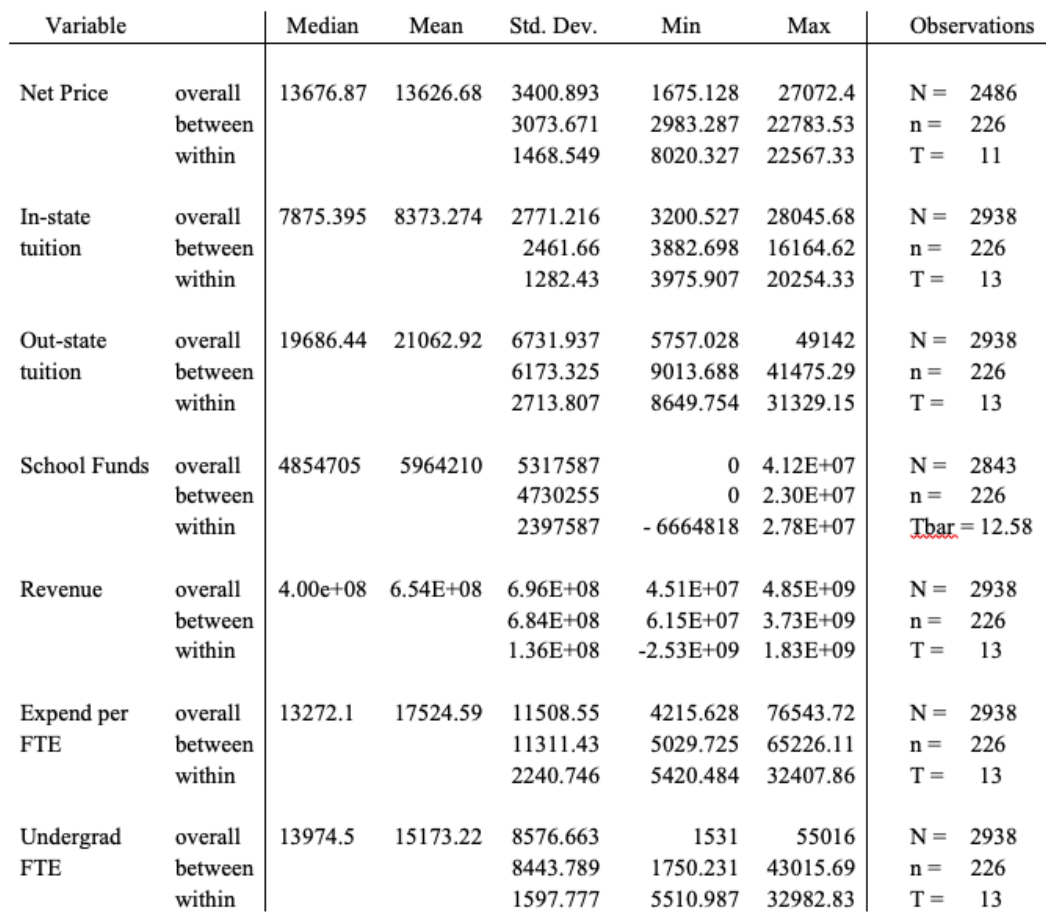

Findings from the regression analyses are presented in Table 2. Before estimating regression models, a Hausman test was run to determine if the independent variables in our estimations were endogenous. The null hypothesis of the Hausman test was rejected at the $99 \%$ confidence level, meaning fixed-effects were appropriate 


\section{Higher Education Politics \& Economics}

for the analysis. In all models in Table 2, year fixed-effects were jointly significant at the $99 \%$ confidence level.

Table 2

Findings from Regression Equations Predicting Student Costs, 2005-2017

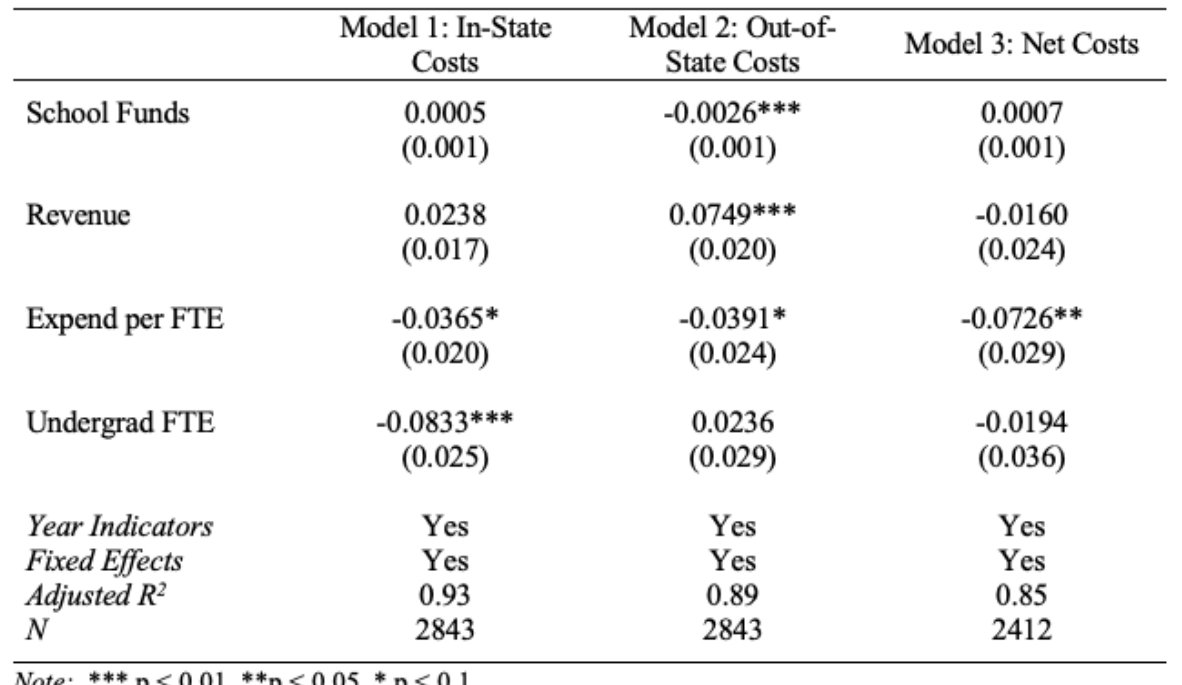

Model 1 of Table 2 shows that a one percent increase in university funds correlated with a $0.0005 \%$ decrease in in-state tuition and fees the following year. This coefficient was not statistically significant. Model 2 indicates that a one percent increase in university funds correlated with a $0.003 \%$ decrease in out-of-state tuition and fees the following year. This coefficient was statistically significant, but practically very small. For the median university in this dataset, a 5\% increase in university funds given to athletics would correlate with a $\$ 315$ reduction in out-ofstate tuition and fees the following year. Model 3 shows that a one percent increase in university funds correlated with a $0.0007 \%$ increase in net student costs the following year. This coefficient was not statistically significant.

Table 3 through Table 5 shows the regression coefficients for models which included interaction terms. The first moderating variable included in our regression models was university tuition setting authority. Of the 226 universities in our analytic sample, $9 \%$ were in states were tuition was set at the legislative level, $45 \%$ were in states where tuition was set at the state board of education or state board of higher education level, and $46 \%$ were in states where tuition was set at the campus board level. As shown in Table 3, this interaction term was not statistically significant in models predicting in-state costs and out-of-state costs. In models predicting student net price, however, the moderating variable was statistically significant. At universities in states where tuition setting authority was at the legislative level, a one present increase in university funds correlated with a $0.01 \%$ decrease in net price. 
The beta coefficients for universities in states were tuition is set at the state or campus board level were larger and significantly different at the $99 \%$ confidence level.

Table 3

Findings from Regression with Interaction by Campus Tuition Setting Authority, 2005-2017

\begin{tabular}{|c|c|c|c|}
\hline & $\begin{array}{c}\text { Model 1: In-State } \\
\text { Costs }\end{array}$ & $\begin{array}{l}\text { Model 2: Out-of- } \\
\text { State Costs }\end{array}$ & Model 3: Net Costs \\
\hline School Funds (SF) & $\begin{array}{c}-0.0038 \\
(0.004)\end{array}$ & $\begin{array}{l}0.0026 \\
(0.004)\end{array}$ & $\begin{array}{c}-0.0117 * * \\
(0.005)\end{array}$ \\
\hline SF X State Board & $\begin{array}{l}0.0047 \\
(0.004)\end{array}$ & $\begin{array}{l}-0.0046 \\
(0.005)\end{array}$ & $\begin{array}{c}0.0133 * * \\
(0.005)\end{array}$ \\
\hline SF X Campus Board & $\begin{array}{l}0.0044 \\
(0.004)\end{array}$ & $\begin{array}{l}-0.0060 \\
(0.005)\end{array}$ & $\begin{array}{c}0.0129 * * \\
(0.005)\end{array}$ \\
\hline Revenue & $\begin{array}{l}0.0242 \\
(0.017)\end{array}$ & $\begin{array}{l}0.0734^{* * *} \\
(0.020)\end{array}$ & $\begin{array}{l}-0.0141 \\
(0.024)\end{array}$ \\
\hline Expend per FTE & $\begin{array}{c}-0.0369^{*} \\
(0.020)\end{array}$ & $\begin{array}{l}-0.0390 \\
(0.024)\end{array}$ & $\begin{array}{c}-0.0737 * * \\
(0.029)\end{array}$ \\
\hline Undergrad FTE & $\begin{array}{c}-0.0849 * * * \\
(0.025)\end{array}$ & $\begin{array}{l}0.0259 \\
(0.029)\end{array}$ & $\begin{array}{l}-0.0253 \\
(0.036)\end{array}$ \\
\hline Year Indicators & Yes & Yes & Yes \\
\hline Fixed Effects & Yes & Yes & Yes \\
\hline Adjusted $R^{2}$ & 0.93 & 0.90 & 0.85 \\
\hline$N$ & 2843 & 2843 & 2412 \\
\hline
\end{tabular}

Table 4 displays the results of regression models where university type was used as the moderating variable. Seventy percent of our analytic sample were research universities and 30\% were non-research universities. For predictions of in-state costs (at the 90\% confidence level) and out-of-state costs (at the 95\% confidence level), university type was a statistically significant modifying variable. The correlation between university funds and in-state and out-of-state costs was slightly more positive at research universities relative to non-research universities. In predictions of net student costs, however, the interaction term was not statistically significant.

Table 4

Findings from Regression with Interaction by Institutional Type, 2005-2017 


\begin{tabular}{lccc}
\hline & $\begin{array}{c}\text { Model 1: In-State } \\
\text { Costs }\end{array}$ & $\begin{array}{c}\text { Model 2: Out-of- } \\
\text { State Costs }\end{array}$ & Model 3: Net Costs \\
\hline School Funds (SF) & -0.0023 & $-0.0064^{* * *}$ & 0.0009 \\
& $(0.002)$ & $(0.002)$ & $(0.002)$ \\
SF X Research Univ & $0.0035^{*}$ & $0.0047^{* *}$ & -0.0002 \\
& $(0.002)$ & $(0.002)$ & $(0.003)$ \\
Revenue & & & \\
& 0.0214 & $0.0716^{* * *}$ & -0.0158 \\
Expend per FTE & $(0.017)$ & $(0.020)$ & $(0.024)$ \\
& & & \\
& $-0.0351^{*}$ & -0.0372 & $-0.0727^{* *}$ \\
Undergrad FTE & $(0.020)$ & $(0.024)$ & $(0.029)$ \\
& $-0.0822^{* * *}$ & & \\
& $(0.025)$ & 0.0251 & -0.0194 \\
Year Indicators & & $(0.029)$ & $(0.036)$ \\
Fixed Effects & Yes & Yes & Yes \\
Adjusted $R^{2}$ & Yes & Yes & Yes \\
$N$ & 0.93 & 0.90 & 0.85 \\
& 2843 & 2843 & 2412 \\
\hline
\end{tabular}

Notes: ${ }^{\cdots} \mathrm{p}<0.01,{ }^{*} \mathrm{p}<0.05,{ }^{*} \mathrm{p}<0.1$

Omitted Group: Non-research universities

Table 5

Findings from Regression with Interaction by Athletics Allocations as a Percentage of Total Institutional Expenditures, 2005-2017

\begin{tabular}{lccc}
\hline & $\begin{array}{c}\text { Model 1: In-State } \\
\text { Costs }\end{array}$ & $\begin{array}{c}\text { Model 2: Out-of- } \\
\text { State Costs }\end{array}$ & Model 3: Net Costs \\
\hline Funds X Perc of Expend & -0.1431 & $1.2861^{* * *}$ & 0.5101 \\
& $(0.350)$ & $(0.410)$ & $(0.512)$ \\
School Funds & 0.0007 & $-0.0017^{*}$ & 0.0018 \\
& $(0.001)$ & $(0.001)$ & $(0.001)$ \\
Percentage of Expend & 2.2452 & $-21.8206^{* * *}$ & -9.7737 \\
& $(5.863)$ & $(6.880)$ & $(8.579)$ \\
Revenue & 0.0199 & $0.0705^{* * *}$ & -0.0172 \\
& $(0.018)$ & $(0.021)$ & $(0.024)$ \\
Expend per FTE & $-0.0361^{*}$ & $-0.0533^{* *}$ & $-0.0797^{* * *}$ \\
& $(0.021)$ & $(0.024)$ & $(0.029)$ \\
& & & -0.0407 \\
Undergrad FTE & $-0.0835^{* * *}$ & 0.0056 & $(0.037)$ \\
& $(0.025)$ & $(0.030)$ & \\
Year Indicators & & & Yes \\
Fixed Effects & Yes & Yes & Yes \\
Adjusted $R^{2}$ & 0.92 & 0.89 & 0.85 \\
$N$ & 2801 & 2801 & 2376 \\
\hline Notes: ${ }^{* * *} \mathrm{p}<0.01, * \mathrm{p}<0.05, \mathrm{p}<0.1$ & &
\end{tabular}

Notes: ${ }^{\cdots}{ }^{\mathrm{p}}<0.01,{ }^{* \mathrm{p}}<0.05,{ }^{*} \mathrm{p}<0.1$

The final moderating variable used in this study was athletics allocations as a percentage of total university expenditures. For the average university in this dataset 
over the 13 years studied, university funds allocated to athletics accounted for about $1.7 \%$ (ranging from $0 \%$ to $17 \%$ ) of total university expenditures with a between university standard deviation of 0.017 and a within university standard deviation of 0.007. Table 5 shows that athletics allocations as a percentage of total university expenditures is not a statistically significant moderator in predicting in-state costs and net costs.

\section{Table 6}

Marginal Effects of School Funds on Out-of-State Tuition and Fees at Various Levels of Athletics Allocations as a Percentage of Total Institutional Expenditures, 2005-2017

\begin{tabular}{|c|c|}
\hline & Out-of-State Costs \\
\hline Perc of Expend @ 0\% & $\begin{array}{c}-0.002 \\
(0.001)\end{array}$ \\
\hline Perc of Expend @ 3\% & $\begin{array}{c}0.037^{* *} \\
(0.013)\end{array}$ \\
\hline Perc of Expend @ 6\% & $\begin{array}{c}0.075^{* *} \\
(0.025)\end{array}$ \\
\hline Perc of Expend @ 9\% & $\begin{array}{c}0.114^{* *} \\
(0.037)\end{array}$ \\
\hline Perc of Expend @ 12\% & $\begin{array}{c}0.153^{* *} \\
(0.049)\end{array}$ \\
\hline Perc of Expend @ 15\% & $\begin{array}{c}0.191^{* *} \\
(0.062)\end{array}$ \\
\hline $\begin{array}{l}\text { Year Indicators } \\
\text { Fixed Effects } \\
N\end{array}$ & $\begin{array}{c}\text { Yes } \\
\text { Yes } \\
2801\end{array}$ \\
\hline
\end{tabular}

The interaction term in Model 2 of Table 5, however, was statistically significant. To help with the interpretation of this coefficient, the marginal effect of university funds on out-of-state costs at various levels of athletics allocations as a percentage of total university expenditures were calculated. These marginal effects are presented in Table 6. When athletics allocations were around zero percent of a university's total expenditures, a one percent increase in university funds correlated with a $-0.002 \%$ reduction in out-of-state costs the following year. When athletics allocations were around nine percent of a university's total expenditures, however, a one percent increase in university funds correlated with a $0.11 \%$ increase in out-of-state costs the following year. At universities where funds to athletics were a larger percentage of the overall budget the relationship between university funds and out-of-state costs became increasingly more positive. These marginal effects are graphed in Figure 3. The findings suggest that, controlling for other factors, universities that devote a larger share of their budget to athletics are more likely to increase out-of-state tuition and fees in response to an increased need to support athletics through university funds. 


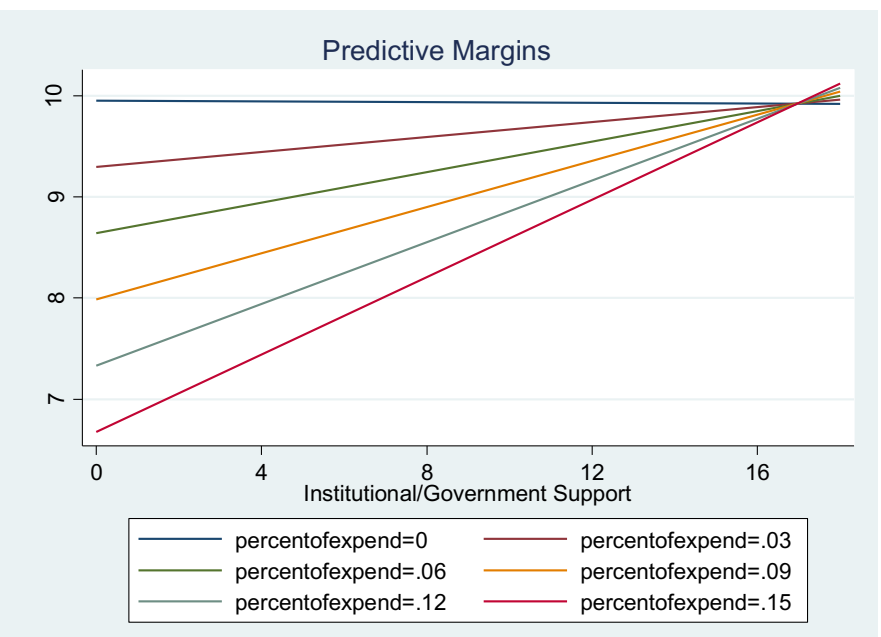

\section{Figure 3. Graph of marginal effects of school funds on out-of-state tuition and fees at various levels of athletics allocations as a percentage of total institutional expenditures, 2005-2017.}

Checks were performed to explore the robustness of our estimation models to alternative specifications. First, we examined whether the relationship between university funds and student costs was nonlinear by including a quadratic term in our base estimation models. This quadratic term was insignificant in all our estimation models. Second, we ran model estimations without log transforming variables to address potential concerns about the function form assumptions of $\log$ transformations. Models using non-transformed data showed results very similar to the results presented in this study.

\section{DISCUSSION}

One of the more significant challenges facing postsecondary education in the United State is rising costs. High college costs is making postsecondary education less accessible to many individuals in middle- and lower-income brackets. Rising college costs also help push up student debt, which one report claims has had a disastrous domino effect on millions of Americans (Hembree, 2018). Some commentators suggest that university spending on intercollegiate athletics is at least partially to blame for rising college costs (Center for College Affordability and Productivity, 2010; Ehrenberg, 2000; Miller, 2003). This argument, however, has been largely empirically untested. This study is, to our knowledge, among the first to quantitatively examine whether universities look to recover revenue used to aid intercollegiate athletics by raising student tuition and fees.

Overall, we found that year to year changes in university funds allocated to athletics have very little impact on student costs. Because all the universities in this 
dataset are public, most students at these universities likely pay in-state tuition and fee rates. None of our estimation models found a statistically significant correlation between changes in university funds and published in-state tuition and fees. Most students attending universities in our sample saw no change in their published tuition and fees based on changes in the amount of financial support allocated to intercollegiate athletics.

Findings related to net student costs were very similar to those related to instate costs. Most estimation models failed to find a statistically significant relationship between net costs and university funds to athletics. The one exception was when an interaction term for university funds and campus tuition setting authority was utilized. In that model, the relationship between yearly changes in university funds and net costs was negative and statistically significant at universities where tuition setting authority was at the legislative level. When tuition setting authority was at the state or university board level, however, the beta coefficient for the university funds-net costs relationship was insignificant. A potential explanation for this finding is that because state representatives face public pressure from voters to limit student costs increases, policymakers in those states work to limit tuition and fee increases regardless of what is spent on athletics. This pattern somewhat manifests itself in models estimating in-state costs (see Model 1, Table 3) as the beta coefficient for the university funds-in-state costs relationship when tuition setting authority was at the legislative level was negative, but the beta coefficients were positive when tuition setting authority was at the state or university board level. It is important to note, however, that the statistically significant beta coefficient for the university funds-net costs relationship where tuition setting authority was at the legislative level is very small, calling into question the practical significance of the finding.

Findings related to out-of-state student costs tell an interesting and slightly more nuanced story. Our base regression model showed a small statistically significant negative correlation between out-of-state costs and changes in university funds. Further analysis showed that this was largely driven by the fact that at most universities in this dataset athletics allocations were a very small percentage of a university's overall budget. As shown in Table 6, when university funds as a percentage of total university expenditures was close to zero, the correlation between university funds and published out-of-state costs is negative. Of the 2801 universityyear observations, $46 \%$ reported that university funds were less than $1 \%$ of the university's budget. This finding is consistent with the larger narrative of our findings. Though some students, faculty, and staff scoff at the amount of money allocated to athletics, for many NCAA Division I universities this allocation is only a small part of the total university budget. At universities where athletics expenditures are a very small portion of university expenditures, year to year increases in university funds do not directly lead to higher costs for out-of-state students.

At universities where university funds are a larger percentage of the budget, however, we do find evidence of a small statistically significant relationship between university funds and out-of-state student costs. This is an important finding to highlight. Out-of-state students attending universities which dedicate a larger 


\section{Higher Education Politics \& Economics}

percentage of their budget to athletics saw an increase in costs when universities allocated more financial resources to athletics. Universities in our sample with a larger percentage of their budget going towards athletics allocations typically have fewer budget resources and enroll students from lower socio-economic backgrounds. This creates some concern that athletics allocations are "regressive" in that they disproportionally impact lower-income students verses higher-income students (Denhart \& Vedder, 2010). This concern is somewhat lessened because this positive relationship was only found for out-of-state students (who typically come from higher income brackets). Given that there is significantly less pressure on public universities to control out-of-state costs, it is not surprising that some universities would look to recapture athletics allocations by raising prices on out-of-state students. As with other significant findings in this study, however, the beta coefficients in Table 6 may be viewed by some as practically small.

\section{Implications}

These findings offer important evidence to inform the ongoing debate on rising college costs. Higher education leaders and policymakers hoping to contain college costs must first determine the important drivers of costs. There remains, however, considerable theoretical and practical debate over why college costs are increasing so rapidly (Cheslock et al., 2016; Wexler, 2016). Our study suggests that yearly increases in university funds play at most only a marginal role in the growing problem of college costs. Our findings are similar to those of Kelchen (2016) who found no statistically significant relationship between athletics expenditures and student fees.

This calls into question the narrative that changing university funds allocated to athletics translate into higher student costs. Faculty, administrators, students, and state representatives concerned with college affordability might tempter the direct blame assigned to increasing athletics allocation for rising student costs. Policy changes designed to limit the amount of university support given to athletics appear likely to have only a marginal effect on student costs. For example, a legislative bill from Virginia adopted in 2015 prohibits the sum of university funds and student fees used to support intercollegiate athletics programs from exceeding a certain percentage of athletics revenues at four-year public institution of higher education in the state. The bill was introduced by Kirk Cox, the Virginia House Majority Leader at the time, who argued that athletics allocation "has been one of the major drivers behind a 122 percent increase in tuition and fees since 2002" (Minium, 2015, par 3). Our research suggests that bills such as this are unlikely to significantly lower college costs given the lack of a strong correlation between university funds and student costs.

We temper our conclusions somewhat by noting that our findings could be driven by modeling decisions. By utilizing a fixed effects regression framework, we capture the average within-university effect of changes in university funds to athletics on student costs. We do not capture how between-university differences in the amount of university funds allocated to athletics correlates with student costs. Future work looking to further quantify whether universities that spend more on athletics 
allocations have higher student costs would be a valuable contribution to our understanding of the role athletics spending plays in student college costs.

If public universities are not compensating for increasing university funds by raising student prices (as suggested by Bowen's theory), they may instead engage in cost-cutting strategies that could impact the quality of the education they can provide. For example, it could be that when universities are forced to allocate additional university funds to athletics, they reduce the amount of funding for other areas such as student services, facilitates maintenance, or instructional support in the form of tenure-track faculty. Schools may also do what the University of Michigan did in 1991. Through creative financing, the University of Michigan used money from a National Science Foundation research grant to aid athletics department expenditures related to their football team's Rose Bowl appearance (Cooper, 1991). This represents an interesting and important area of future research. While we show that rising university funds do not significantly impact what students pay, university funds could indirectly impact the quality of the education students receive.

\section{CONCLUSION}

Our findings should serve as a first step in a more critical analysis of how the higher education community looks at intercollegiate athletics in relation to student costs. There is plenty to criticize regarding the money involved in college sports and the amount some universities must invest for big-time athletics to be sustainable. Making a direct link between year to year increases in university funds and student costs, however, appears to be spurious at public NCAA Division I universities. By helping to better pinpoint the variables which do and do not lead to higher student costs, it is hoped that this study will help lead to policies and practices that better address the causes of rising student costs and reduced college affordability.

\section{REFERENCES}

Ahmed, S., \& Ghosh, A. (2012). Tuition Elasticity: Student Responsiveness to Tuition Increases. $\quad$ http://www.hanoverresearch.com/2012/06/28/tuition-elasticitystudent-responsiveness-to-tuition-increases/.

Alexander, D., \& Kern, W. (2009). The impact of athletic performance on tuition rates. International Journal of Sport Finance, 4, 240-254. http://fitpublishing.com/journals/ijsf

Alexander, D., \& Kern, W. (2010). Does Athletic Success Generate Legislative Largess from Sports-Crazed Representatives? The Impact of Athletic Success on State Appropriations to Colleges and Universities. International Journal of Sport Finance, 5, 253-267. http://fitpublishing.com/journals/ijsf

Allison, P. D. (2009). Fixed effects regression models. SAGE publications.

American Academy of Arts and Sciences. (2016). Public research universities: Understanding the financial model. https://www.amacad.org/content/publications/publication.aspx?d=22069.

Art \& Science Group. (2011). Quantitative and Qualitative Research with Football Bowl Subdivision University Presidents on the Costs and Financing of 


\section{Higher Education Politics \& Economics}

Intercollegiate Athletics: Report of Findings and Implications. http://www.knightcommissionmedia.org/images/President_Survey_FINAL.pdf.

Balzer, W. K. (2020). Lean higher education: Increasing the value and performance of university processes. Taylor \& Francis.

Bass, J. R., Schaeperkoetter, C. C., \& Bunds, K. S. (2015). The "front porch": Examining the increasing interconnection of university and athletic department funding. ASHE Higher Education Report, 41, 1-103. https://doi.org/10.1002/aehe.20023

Berkowitz, S., \& Upton, J. (2011). Rutgers athletic department needs fees, funds to stay afloat. Retrieved November 15 from http://www.usatoday.com/sports/college/2011-06-28-rutgers-athleticdepartment-subsidies_n.htm.

Burgess, B. (2011). Evaluating the Policies that Lead to Substantial Tuition Variation at Public Land-Grant Universities. Planning for Higher Education, 39, 25-33. https://www.scup.org/learning-resources/planning-for-higher-educationjournal/

Burnsed, B. (2014, August 20). Growth in Division I athletics expenses outpaces revenue increases http://www.ncaa.org/about/resources/media-center

Center for College Affordability and Productivity. (2010). 25 Ways to Reduce the Cost of College. http://centerforcollegeaffordability.org/uploads/25Ways_to_Reduce_the_Cost_ of_College.pdf.

Cheslock, J. J., \& Knight, D. B. (2015). Diverging revenues, cascading expenditures, and ensuing subsidies: The unbalanced and growing financial strain of intercollegiate athletics on universities and their students. The Journal of Higher Education, 86 ,

417-447. https://doi.org/http://dx.doi.org/10.1080/00221546.2015.11777370

Cheslock, J. J., Ortagus, J. C., Umbricht, M. R., \& Wymore, J. (2016). The Cost of Producing Higher Education: An Exploration of Theory, Evidence, and Institutional Policy. In M. B. Paulsen (Ed.), Higher education: Handbook of theory and research (pp. 349-392). Springer.

College Athletics Financial Information Database. (2020). Knight Commission on Intercollegiate Athletics. Athletics Data Source: USA TODAY's NCAA Athletics Finance Database. www.knightcommission.org.

Cooper, K. (1991, September 11). Rose Bowl expenses billed as research costs: University of Michigan charges questioned. Washington Post, A21.

Delaney, J. A., \& Kearney, T. (2014). The Impact of Guaranteed Tuition Policies on Postsecondary Tuition Levels: A Difference-in-Difference Approach. The Association for Education Finance and Policy Annual Conference, San Antonio, TX.

Denhart, M., \& Ridpath, D. (2011). Funding the Arms Race: A Case Study of Student Athletic Fees. http://www.centerforcollegeaffordability.org/uploads/Funding_the_Arms_Race .pdf

Denhart, M., \& Vedder, R. (2010). Intercollegiate Athletics Subsidies: A Regressive Tax. https://files.eric.ed.gov/fulltext/ED536486.pdf 
Desrochers, D. M. (2013). Academic Spending Versus Athletic Spending: Who Wins? http://www.deltacostproject.org/pdfs/DeltaCostAIR_AthleticAcademic_Spendi ng_IssueBrief.pdf

Dosh, K. (2013). Saturday millionaires: How winning football builds winning colleges. Wiley.

Doyle, W. R. (2012). The politics of public college tuition and state financial aid. The Journal of Higher Education, 83, 617-647. https://doi.org/https://doi.org/10.1080/00221546.2012.11777260

Ehrenberg, R. G. (2000). Tuition rising: Why college costs so much. Harvard University Press.

Fear, F. (2016, April 27). Money issues accumulate in major college sports. The Sports Column. http://www.thesportscol.com/2016/04/money-issuesaccumulate-in-major-college-sports/

Fulks, D. (2017). NCAA Division I intercollegiate athletics programs report. http://www.ncaa.org/sites/default/files/2017RES_D1-

RevExp_Entire_2017_Final_20180123.pdf

Fuller, R. D., Berg, B. K., \& Hutchinson, M. (2017). Aspirations Through Association: Using Athletics to Enhance Institutional Prestige. Case Studies In Sport Management, 6, 20-30. https://doi.org/10.1123/cssm.2017-0008

Goff, B. (2000). Effects of university athletics on the university: A review and extension of empirical assessment. Journal of Sport Management, 14, 85-104. http://journals.humankinetics.com/jsm

Hembree, D. (2018, November 1). New Report Finds Student Debt Burden Has 'Disastrous Domino Effect' On Millions Of Americans. Forbes. https://www.forbes.com/sites/dianahembree/2018/11/01/new-report-findsstudent-debt-burden-has-disastrous-domino-effect-on-millions-ofamericans/\#679d210612d1

Hobson, W., \& Rich, S. (2015a, November 23). Playing in the Red. The Washington Post. http:/www.washingtonpost.com/sf/sports/wp/2015/11/23/running-up-thebills/

Hobson, W., \& Rich, S. (2015b, November 30). Why students foot the bill for college sports, and how some are fighting back. The Washington Post. https://www.washingtonpost.com/sports/why-students-foot-the-bill-for-collegesports-and-how-some-are-fighting-back/2015/11/30/7ca47476-8d3e-11e5-ae1faf46b7df8483 story.html?utm term=.9cc1594db5a9

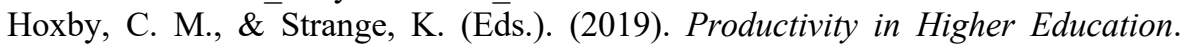
University of Chicago Press.

IPEDS Help Desk. (2020). IPEDS 2020-2021 data collection system glossary. https://surveys.nces.ed.gov/ipeds/public/glossary.

Kearney, T. D. (2014). Three essays on intercollegiate athletics and the financial relationship with institutions of higher education [Unpublished doctoral dissertation, University of Illinois at Urbana-Champaign].

Kelchen, R. (2016). An Analysis of Student Fees: The Roles of States and Institutions. The Review of Higher Education, 39, 597-619. https://doi.org/10.1353/rhe.2016.0027 


\section{Higher Education Politics \& Economics}

Knight Commission on Intercollegiate Athletics. (2010). Restoring the balance: Dollars, values, and the future of college sports. https://www.knightcommission.org/wp-content/uploads/2017/09/restoring-thebalance-0610-01.pdf

Koshal, R., \& Koshal, M. (2000). State appropriation and higher education tuition: What is the relationship? Education Economics, 8, 81-89. https://doi.org/https://doi.org/10.1080/096452900110319

Lederman, D. (2012, January 10). College Sports Reform: Now? Never? Inside Higher Ed. https:/www.insidehighered.com/news/2012/01/10/calls-majorreform-college-sports-unlikely-produce-meaningful-change

McEvoy, C. D., Morse, A. L., \& Shapiro, S. L. (2013). Factors influencing collegiate athletic department revenues. Journal of Issues in Intercollegiate Athletics, 6, 249-267. http://csri-jiia.org/

Miller, R. (2003). The role of athletics in higher education. Major Themes in Economics, 5, 31-47. https://scholarworks.uni.edu/mtie/

Minium, H. (2015, March 31). McAuliffe signs bill that limits athletic student fees. The Virginian-Pilot. https://pilotonline.com/sports/mcauliffe-signs-bill-thatlimits-athletic-student-fees/article_337e7bec-d46e-5e15-bba66fc8de3a5f01.html

Phillips, C. R., \& Olson, J. E. (2015). To what extent are the final cost objectives of universities subsidized? Review of Business, 36, 113-129. http://www.stjohns.edu/academics/schools-and-colleges/peter-j-tobin-collegebusiness/college-faculty/review-business-journal

Pope, D. G., \& Pope, J. C. (2009). The impact of college sports success on the quantity and quality of student applications. Southern Economic Journal, 75, 750-780. http://journal.southerneconomic.org/

Rabe-Hesketh, S., \& Skrondal, A. (2008). Multilevel and longitudinal modeling using Stata. STATA press.

Rascher, D., \& Schwarz, A. (2015). The Incremental Benefits and Costs of Football, Bowling, and Rifle at the University of Alabama at Birmingham. http://a.espncdn.com/pdf/2015/0423/UABAthleticsFinancialAnalysis_r.pdf

Ridpath, D., Smith, J., Garrett, D., \& Robe, J. (2015). Shaping Policy and Practice in Intercollegiate Athletics: A Study of Student Perceptions of Resource Allocation for Athletics and its Effect on Affordability of Higher Education. Journal of SPORT, 4. https://oaks.kent.edu/sport

Rizzo, M. J., \& Ehrenberg, R. G. (2004). Resident and nonresident tuition and enrollment at flagship state universities. In C. Hoxby (Ed.), College choices: The economics of where to go, when to go, and how to pay for it (pp. 303-354). University of Chicago Press.

Rudolph, M. J. (2017). Do intercollegiate athletics subsidies correlate with educational spending? An empirical study of public division-I colleges and universities [Unpublished doctoral dissertation, University of Kentucky].

Sherfinski, D. (2013). College athletic departments in Virginia get 12 percent of tuition, fees. The Washington Times. https://www.washingtontimes.com/news/2013/sep/9/college-athleticdepartments-in-virginia-get-an-av/ 
Sherlock, M. F. (2011). Reducing the Budget Deficit: Tax Policy Options. http://www.fas.org/sgp/crs/misc/R41641.pdf.

Smith, D. R. (2012). The curious (and spurious?) relationship between intercollegiate athletic success and tuition rates. International Journal of Sport Finance, 7, 318. http://fitpublishing.com/journals/ijsf

Suggs, W. (2009). Old challenges and new opportunities for studying the financial aspects of intercollegiate athletics. New Directions for Higher Education(148), $11-22$.

Toma, J. D. (2010). Intercollegiate Athletics, Institutional Aspirations, and Why Legitimacy Is More Compelling than Sustainability. Journal of Intercollegiate Sport, 3, 51-68. https://doi.org/10.1123/jis.3.1.51

U.S. Department of Education. (2019). The Condition of Education 2019 (NCES 2019-144).

https://nces.ed.gov/fastfacts/display.asp?id=75\#: :text=In $\% 202016 \% \mathrm{E} 2 \% 80 \%$

9317\%2C\%20degree $\% 2 \mathrm{D}$, at $\% 20$ private $\% 20$ for $\% 2$ Dprofit $\% 20$ institutions.

USA Today Sports. (2017, July 6). Methodology for 2016 NCAA athletic department revenue database.

USA

Today.

http://sports.usatoday.com/2017/07/06/methodology-for-2016-ncaa-athleticdepartment-revenue-database/

Wexler, E. (2016, February 9). Why Is Tuition So High? Inside Higher Ed. https://www.insidehighered.com/news/2016/02/09/study-increased-student-aidnot-faculty-salaries-drives-tuition

Wolverton, B., Hallman, B., Shifflett, S., \& Kambhampati, S. (2015, Novermber 15). Sports at any cost: How college students are bankrolling the athletics arms race. Huffington Post. http://projects.huffingtonpost.com/ncaa/sports-at-any-cost

Wunderlich, D. (2013). Be Careful With USA Today's College Finances Database. http://www.teamspeedkills.com/2013/5/8/4311070/usa-today-college-financesdatabase-2012.

Zinth, K., \& Smith, M. (2012). Tuition-Setting Authority for Public Colleges and Universities. https://www.ecs.org/clearinghouse/01/04/71/10471.pdf

\section{FOOTNOTES}

${ }^{1}$ The NCAA divides colleges and universities into three divisions. Division $\mathrm{I}$ is the highest level of athletics competition sanctioned by the NCAA. Universities in Division I typically sponsor more sports, have larger athletics budgets, and have more elaborate facilities relative to colleges and universities competing at the Division II or Division III level. For more information on the NCAA organizational structure, please see http://www.ncaa.org/about/resources/media-center/ncaa-101/our-threedivisions or http://www.ncaa.org/about/resources/media-center/ncaa-101/what-ncaa 2 There is some debate about the validity of reported athletics department shortfalls and about what is and what is not considered an allocation to an athletics department. Please see Rascher and Schwarz (2015), Goff (2000), and Dosh (2013) for more about this debate.

${ }^{3}$ Public universities in Pennsylvania are not required to respond to public records requests. 
WILLIS A. JONES, PhD, is an associate professor of higher education and student affairs at the University of South Florida. His primary area of research examines the economics and finances of intercollegiate athletics. jonesw150@usf.edu

MIKE RUDOLPH, PhD, is the Director of Institutional Effectiveness in the Provost's Office and an adjunct faculty member in the College of Education at the University of Kentucky. His primary research interests include planning, assessment, and budgeting in higher education. michael.rudolph@uky.edu 